\title{
On Rousseau's Love Outlook and His Civilian Complex
}

\author{
Xiaoying Li1 ${ }^{1}$, Yingfei Yuan² \\ ${ }^{1}$ Foreign Languages School, Sichuan Medical University, Luzhou, China \\ ${ }^{2}$ Basic Medical School, Sichuan Medical University, Luzhou, China \\ Email: lixiaoying740516@163.com, 498487312@qq.com
}

Received 12 October 2015; accepted 25 October 2015; published 28 October 2015

Copyright $@ 2015$ by authors and Scientific Research Publishing Inc.

This work is licensed under the Creative Commons Attribution International License (CC BY). http://creativecommons.org/licenses/by/4.0/

c) (i) Open Access

\begin{abstract}
Rousseau had some peculiar love experiences which many people couldn't understand, especially the experience with the servant Therese le Vasseur. So in the article, I explored his life background, his love experiences and analyzed his love outlook. Certainly, his love outlook was related to his love experiences and his love experiences also were related to his civilian complex. I might say that his love experiences, love outlook and civilian complex answered people's doubt that was why he chose Therese le Vasseur to spend his rest of his life.
\end{abstract}

\section{Keywords}

Rousseau, Love Experiences, Love Outlook, The Civilian Complex

\section{Introduction}

Jean Jacques Rousseau, though a very famous philosopher, was a very talented and romantic person, and to some degree, a little dissolute in people's minds. In The Confession, he stated a lot of his love stories and feelings, which seemed very immoral and absurd in the sexual aspect, but he didn't realize it and he showed unintentionally his appreciation on himself and trying to defend him in everywhere. He had some special and peculiar love stories and experiences in his life. For example, the love he had for Madame de Warens, who got pensions from king of Savoy every year, a convert from Protestantism. The life between him and Therese le Vasseur, who was a servant at his hotel in Paris was unimaginable. For this, people became very interested in his love outlook, so did I. People especially wanted to know why he lived and loved Therese le Vasseur for the rest of life. She was ugly and ignorant; she could neither read nor write (later Rousseau taught her to write, but not to read); she did not know the names of the months, and could not add up money. In fact, as to this affair with Madame de Warren he chose, this was related to the plot between his love outlook and his civilian complex, that 
was very difficult for the most to understand. Now, I would like to analyze and explore Rousseau's love outlook and sources for forming it from several aspects.

\section{The Life Background of Rousseau}

He was born at Geneva in the year 1712, and educated as an orthodox Calvinist. His father, who was poor, combined the professions of watchmaker and dance-master. His mother a daughter of the Protestant minister Bernard, died when he was an infant, and he was brought up by an aunt, who was an amiable and virtuous woman. His father loved his mother very much. Of all the gifts which Heaven had bestowed upon his parents, a sensitive heart was the only one they bequeathed to him. A sensitive heart had been the source of his parents' happiness, but for Rousseau it proved the source of all the misfortunes of his life. He left school at the age of twelve, and was apprenticed to various trades, but hated them all, and at the age of sixteen fled from Geneva to Savoy. Having no ways of subsistence, he went to a Catholic priest and represented himself as wishing to be converted. The formal conversion took place at Turin, in an institution for catechumens; the process lasted nine days. He represents his motives as wholly mercenary: "I could not dissemble from myself that the holy deed I was about to do was at bottom the act of a bandit” (Rousseau, 1997). But this was written after he had reverted to Protestantism, and there is reason to think that for some years he was a sincerely believing Catholic. So we can see the background of Rousseau was not good and very unhappy and complicated. To some part, it had an effected on Rousseau's life and forming of his all kinds of outlooks deeply. The most importance is that his background and experiences made him form a romantic, sensitive and simple character.

\section{Some Experiences with Love before 1744}

When he was eleven he loved two persons at the same time. At that time Rousseau's father settled at Nyon, a little town in the Vaud country, so Rousseau went to see him from time to time, where Rousseau was welcomed, especially a certain Madame de Vulson bestowed a thousand caresses upon him, and, to crown all, her daughter, who was named Mademoiselle de Vulson, twenty-two, took him for her lover. Another girl was Mademoiselle Goton, who was really a singular and not pretty person, but she had a face, which was not easy to forget in Rousseau's eye. The whole of the life was divided between these two kinds of love, which were so different. During that period he belonged entirely to each of the two persons, and so completely, that, when he was with one, he never thought of the other. In other respects, there was not the slight similarity between the feelings. He had the feeling that he could have spent all his life with Mademoiselle de Vulson, without ever thinking of leaving her, but when he approached her, his joy was tranquil and free from emotion. He loved her very much. He felt a real tenderness for her; even he suffered when she was ill, he would have given his own health to restore hers. For the feeling to Mademoiselle de Vulson, he loved her as brother, but he was jealous of her as a lover. His connection with Mademoiselle de Vulson was less lively, but it was perhaps closer. Even they reached the degree that they never separated without tears, and it was wonderful into what an overwhelming void he felt himself plunged as soon as he had left her. Rousseau often wrote to her, pathetic enough to melt the heart of a stone when they were separate. At last he triumphed, she came to Geneva to see him (at that time Rousseau lived at Geneva), but to Rousseau's disappointment, he knew Mademoiselle de Vulson he loved and missed so much had married. He was very angry with this, and so he swore he would never see her. At the same time he also had the feeling that he should have obeyed Mademoiselle Goton, if she had ordered him to throw himself into flames. So we can see Rousseau was full of tenderness and sensitivity when he was in his childhood.

In 1728 he fled to Annecy with great ambition that he thought he could do everything, attain to everything. In the expectation of this modest future, he wondered for some days round the city of Annecy, lodging with some peasants whom he knew, who all received him with greater kindness than any of the habitants of the city would have done. The peasants took him in, lodged him, and fed him with too much kindness to make a merit of it. They did not bestow it with a sufficient air of superiority. This experience satisfied Rousseau and gave him deep impression. He deeply felt the peasant's simplicity and honesty. So in the bottom of Rousseau's heart, he appreciated peasants, to some part he loved them. So I think maybe this was one of the reasons that he chose Therese le Vasseur to live with and spent his rest of his life.

With the timidity of his age was united that of a very loving disposition, always troubled by the fear of displeasing, but luckily, with M. de Pontverre's help, he met Madame de Warens at the year of his sixteen at Annecy, which was the epoch of his life which decided his character. When he saw Madame de Warens for the first 
time, her sight struck him. Before Rousseau saw Madame de Warens, he thought she was an old, grim, religious enthusiast, but instead beheld a face full of charm, beautiful blue eyes-full of gentleness a dazzling complexion, and the outlines of an enchanting throat. Nothing escaped the rapid glance of the young proselyte for at that moment he nearly became hers, feeling convinced that a religion preached by such apostles must inevitably lead to paradise. At that time Madame de Warens was twenty-eight years of age who just had lived in Annecy for six years. Her beauty was of the kind, which lasts, consisting rather in the expression than the features; besides, he was still in its first brilliancy. She had a caressing and tender air, a gentle look, an angelic smile, a mouth like his own, ashen-gray hair of rare beauty, which she wore in a careless fashion, which gave her a very piquant appearance. She was small of stature, even short somewhat dumpy, although not disagreeably so; but a more beautiful head and bosom, more beautiful hands and arms, could not have been seen. This was that Madame de Warens gave Rousseau the first impression that was very wonderful. Besides her beauty, her education was very peculiar. She had learnt a little from her governess, a little from her father, a little from her master, and a great deal from her lovers, especially from one $\mathrm{M}$. de Tavel, who, being a man of taste and learning, adorned the object of his affections with his own excellences. So she knew something about the principles of philosophy and physics, to some degree, she was a little learned and she had loving and gentle character. In her life, her sympathy with the unfortunate, her inexhaustible goodness, her cheerful, frank, and open disposition never changed; even when old age came upon her, surrounded by want, suffering, and calamities of all kinds, the calmness of her beautiful soul preserved for her to the end of her life all the gaiety of her happiest days.

So in Rousseau's eyes, Madame de Warens was a very perfect person, but who was a lady of higher position than him. Therefore, the feeling that Rousseau gave Madame de Warens was very complicated, many people put forward doubt with the love relation between them, just as he said in The Confession: "Granted that my sentiments for her were really love, which will at least appear doubtful to those who follow the history of our relations, how came it that this passion was from the outset accompanied by the feelings which it inspires peace of heart, calm, cheerfulness, confidence, trust? How was it that, when for the first time I approached an amiable, refined, and dazzlingly beautiful woman, a lady of higher position than my own, the like of whom I had never addressed, upon whom my destiny in a manner depended, according as she interested herself more or less on my behalf-how came it, I repeat, that, in spite of all this, I immediately felt as free and completely at my ease as if I had been perfectly certain of pleasing her” (Rousseau, 1997). In fact, he couldn't speak of the love between them clearly because he also said in The Confession: "I was able to assume with her the easy manners, the tender language, the familiar tone which prevailed between us ten years later, when our close intimacy had made it natural? Is it possible to love? Does not one at least wish to learn from the object of one's affection whether one is loved in return? It has no more occurred to me in the course of my life ever to ask her this question than to ask myself whether I loved her; and she never shown greater curiosity in regard to myself” (Rousseau, 1997). But anyhow, during the period when Madame de Warens adopted him, he was happy, though he was not interested in some courses or some jobs. At least he could get security on life from Madame de Warens and she also could create some study and work opportunities for him. On the other hand, he got much pleasure from the life between them when they were together. And he felt very relaxed and freed from burden in his life. He expressed this relax in his recollection that: "Everything that I saw appeared to assure my early happiness. In the houses I pictured to myself rustic festivities; in the meadows, playful romps; on the banks of the rivers, bathes, walks, fishing; on the trees, delicious fruit; under their shade, loving tête-à-têtes; on the mountains, pails full of milk and cream, a charming idleness, peace, simplicity, and the pleasure of going I knew not where. In short, nothing met my eyes without conveying to my heart some attraction of enjoyment” (Rousseau, 1997).

Rousseau and Madame de Warens lived together about for ten years. In the first four years Rousseau regarded Madame de Warens as mamma, of course, during this period he nearly studied in the other places. But later, their feeling between them changed, the relationship between them was lover, though Rousseau still called Madame de Warens mamma. At that time Rousseau was reluctant to leave Madame de Warens. Later he recalled the feeling on the way, when he returned to Annecy, he said: "Nothing flattered or tempted me; my only desire was to return to mamma. The warmth and tenderness of my attachment to her, had uprooted from my heart all imaginary projects, all the follies of ambition. I saw no other happiness than that of living with her, And I never went a step without feeling that I was removing further from this happiness” (Rousseau, 1997). But on his arrival, he didn't see Madame de Warens any longer, she had left for Paris. Later Rousseau came back to see Madame de Warens, to his surprise and disappointment, he found his role, as Madame de Warens young lover had been replaced by another young man. This gave Rousseau heavy strike and he left Madame de Warens with 
great anger.

From then on Rousseau changed his love outlook. He didn't want to depend on the noble ladies who were richer and elder than him. The love experiences he had made him not only happy but also sorrow, especially the love with Madame de Warens. In the bottom of his heart he was constrain because he always tried his best to cater to the ladies whose ages were elder and positions were higher than him when he associated with them. On the other hand, before thirty, besides the associating with his lovers and some noble people, he often associated with the servants and the peasants. When he associated with the noble people he felt constrain, instead, he felt much more relaxed and self-confident when with the servants and peasants. To some degree, we may say he had certain civilian complex. Maybe this was one of the reasons why he spent his rest of life with Therese le Vasseur.

\section{The Life with Therese le Vasseur}

In 1745 he took up with Therese le Vasseur, who was a servant at his hotel in Paris. He lived with her for the rest of his life, certainly not to the exclusion of other affairs; he had five children by her, all of whom he took to the Foundling Hospital. No one has ever understood what attracted him to her. She was ugly and ignorant; she could neither read nor write; she didn't know the names of the months, and couldn't add up money. And her mother was grasping and avaricious. The whole family of Therese le Vasseur used Rousseau and all his friends as sources of income. So Rousseau often became unhappy at this and argued with Therese le Vasseur. Just as Rousseau said he never had a spark of love for Therese le Vasseur. Though he said so, he still lived with her and didn't leave her. Also just this he didn't want to keep his five children and decided to send them to the Foundling Hospital. Certainly, he did so; this was related with his changed outlooks and his civilian complex that he had all the time. So in this article, I analyze his love outlook and civilian complex through his life background and some love experiences to answer people's doubt why Rousseau chose Therese le Vasseur to spend his rest of life.

\section{Conclusion}

Jung said that "character determines destiny" (Jung, 2005). I thought so. Some people thought that he probably liked the feeling that he was indubitably superior to her, both financially and intellectually, and that she was completely dependent upon him. He was always uncomfortable in the company of the great and genuinely preferred simple people. In this aspect, his democratic feeling was wholly sincere. I agreed with this view because before he spent life with Therese le Vasseur, the lovers he loved were always higher positions than him, so he always was a little constrained and careful to the people who were in higher position than him. He chose Therese le Vasseur to live together, who was lower than him, and he could seek some comfort and found back his self-confident. In this respect, I agreed with the people. But I thought that this view was one of the reasons why he did so. The one important reason was that the choice he made was related with his love outlook and civilian complex, which were formed from his experiences. Another reason was that his experiences were unusual from others and were very romantic, so when he became riper in his thought, he wasn't interested in some romantic things and became more realistic. At this time, he devoted himself to doing the research and seeking the reason why he always caused in that situation. From then on, he opposed the advanced science and technology and situations in his opinion. He advocated free and original things, and he also advocated natural things. So maybe, this was the fourth reason why he chose the Therese le Vasseur who was more natural and more original to some degree to spend life with her. In total, Rousseau's love outlook, which deprived from his some love experiences, and the choice he had made in love were tightly related with his civilian complex. But he regretly, he was like a man who was stripped not only of his clothes, but also of his skin during the whole course of his life.

\section{References}

Rousseau, J. J. (1997). The Confession. Beijing: Foreign Teaching and Research Press.

Jung, (2005). Jung's Wisdom: Jung Personality Philosophical Interpretation. Beijing: China Film Press. 